Kohl: a Journal for Body and Gender Research

Vol. 5, No. 2 (Summer 2019)

\title{
Interlude of Another Life
}

\author{
Saada Allaw
}


The beautiful girl who had left Hermel for a distant city, my seven-year-old self used to await her return every season. Baalbek was about sixty kilometers away; we had to travel a hundred kilometers to get to Zahle. I did not visit either until I was fifteen years old, when I had to seek treatment for my asthma.

But this is about her, the girl with the clear white skin and light chestnut hair. My memory escapes me; it can only discern the contours of her jeans, her T-shirt showing cleavage, the handbag she held under her arm, and the backpack she carried on her back, which I always believed to be her home.

I used to wait for her, observe the changes in her demeanor whenever her departure was imminent. Always in a hurry, she came out of nowhere and left as if on a tight schedule. Despite my long waits, the only thing I disliked about her was the flashy, explicit red lipstick that colored her lips. To this day, I am averse to it.

The conversations the women in the neighborhood had about her only construed her as more of a mystery to me. When I heard her name, I would come close, only for their voices to fade in whispers. When I got even closer, they would change the topic. One day, I hid behind a bush of roses at our neighbor's and I discovered her secret, or theirs.

All the other girls were prohibited from befriending her, and those conversations called her "reputation" into question. Whether in rural or urban settings, a woman's "reputation" can take on different meanings, but it is always a double-edged sword for our conservative societies: it can destroy her or lift her up the social ladder.

It was only in my adolescent years that I learned the whole truth from my cousin Fatima, who always attended to my lack of information and rectified my acquired misconceptions. Fatima, who worked in politics, from political parties, to women's issues, to the war, based her credibility on a "golden reputation," as they used to say.

One day, the neighborhood was filled with whispers, debates, back-and-forths, and my desperate attempts to know what was going on around me

"They killed your friend," the childhood companion with whom I hunted blackcaps at dawn informed me. She was not a friend; we had never spoken. I merely looked at her, imagining the far-away lives of independent girls, almost grasping the features of distant cities and their urban lives. As I lied next to him under a tree, waiting for the murmuration of the October birds, he said to me: "she did bad things with boys, that's what my mother told me." That day, when I went back home, I asked my own mother, Franjieh, if going hunting with Hussam was "doing a bad thing." That was also when I understood my aversion to red, "flashy" lipstick as a result of Franjieh's education: "respectable girls don't wear strong make-up."

Fatima was the only one to tell me the bitter truth, after all the twisted versions I had been privy to. My murdered "friend" came from a very poor family. With her parents both sick, she and her sisters were forced to clean houses - a beautiful girl working in a house, one of the typical stories where she would be subjected to harassment from everyone in the domestic sphere, even extended members of the family. Hussam 
revealed: "I heard my mother say that they started first." We did not know what harassment meant. "This is why she left for the city," Fatima told me to appease my inquiries, and I understood why she was always in a hurry. Someone said that she worked for a family in Zahle, who gave her a single day off per week, which resulted in her death.

On one of her days off, they took her and killed her. I was later told details that I could never verify. Some said she was brutally left to die alone in a sealed cave. Others recounted that she had been buried alive. My heart aches for her until today.

When I eventually discussed her story with my mother, she told me about another girl I neither knew nor waited for, but who joined my "friend" in my heartbreak.

She had been killed more than twenty years before my "friend" was. At the age of thirteen, her parents left her in the care of a man who was thirty years her senior. She was completely alone with him, in his house, and got pregnant from him. They killed her and her fetus, evading their own guilt and complicity in her rape. She was buried in silence, far from the village, and people kept quiet. As for the man, he was "exiled" from the area for a few years; he eventually returned and life resumed for him as if nothing had happened.

When Ghiwa asked me more than a year ago to write for Kohl about what she dubbed "rural feminisms," I reflected on my rights-based approach to my personal feminism. Deep down, my bias towards this classification is due to all those issues that shaped and shook me and that are still silenced in entire communities, not only among women - knowing that women are at the core of these oppressions. Ghiwa's request brought me involuntarily to their stories as an entry point, making me realize that they had permeated my political consciousness and rights-based feminism. I questioned myself, digging for that consciousness, digging into myself. I had always oriented my feminist "involvement" towards the human being in general, regardless of gender; I believed that "there would be no rights, freedom, or equality for women unless all human beings are liberated, whether men or women." Does my unconscious consider the liberation of men as a pre-condition to that of women, despite me being feminist to the bone? How important is it for me to reveal the roots and how-tos of my feminism? Or determine my bias towards human liberation? And for whose benefit?

The answer might lie in the screaming voice that I can still hear to this day.

That day, I heard a scream that resembled the echo of a gunshot sound coming from our neighbor, followed by a whimper. No one bothered to find out its source or cause. With time, I learned that the neighbor had bitten his wife's ear. She was never the same after that scream; she became gloomier and more reserved. It took me several years to find out that she no longer wore earrings. Her daughter, a childhood friend of mine, told me that her mother had come to hate her mutilated ear, part of which had remained between her husband's teeth. 
I was in fourth grade when I took off the hijab I had been wearing for four months, against my siblings' will. I climbed the high mountain behind our house, gazed at the sky, and told him, told "God," in whose existence I believed: "why do you leave women alone?" Why had he left my "friend," the thirteen-year-old, my neighbor, and her ear, alone?

In recent years, I fiercely fought for the passing of a law that protected women from domestic violence as a journalist and civil society activist, alongside organizations, women, and men. One of the deputies of the parliamentary sub-committee that had reviewed the bill told me: "you seem to have faced a lot of violence." Despite his limited understanding of the struggle and its root-causes, his conclusion made me doubt and question myself.

Had I really been subjected to violence? And does violence need to be direct to leave traces? Is it because my father believed in my mental faculties? I was the least "beautiful" among my sisters, according to the normative standards of beauty, and he had considered my "intelligence" to be my capital, rather than my physical appearance.

I was about three-years-old, maybe a bit less, when my father told me: "you are stuffed with intelligence." I replied: "I am not a tucchini to be stuffed." I said tucchini instead of zucchini as I was not able to pronounce all the letters yet, which is why I believe I had not reached three years of age then.

Every time he had a guest, which was a frequent occurrence in our house, my dad would call me. I would join him, and he would say to his visitors: "I have this daughter who's stuffed with intelligence," to which I would invariably reply: "I am not a tucchini to be stuffed." This ritual was my first boost of self-confidence, enhanced by my father's pride in cultivating my so-called "intelligence" so he could invest in it in later years.

When I participated in the Hermel and Northern Bekaa running championship and won the first place, he told me: "you are the stallion of the house" - the horse he used to tend to every morning with a glass of milk and a spoon of honey, a rare treat in a poor house like ours. When we went to Hermel every year, we left our thoroughbred stallion behind, in Marjahin, despite the harshness of winter and the presence of wild beasts, particularly wolves. We used to take the colt along to the plains instead. My father used to remove the stallion's bridle and let her roam free. Every winter, he would repeat, "the wolf cannot overpower a free, unbridled thoroughbred stallion." Involuntarily, this analogy shaped my understanding of embodying the "stallion of the house." In my imaginary, I was a free stallion that could not be overpowered by the beasts, a certitude that filled my teenage lungs like oxygen.

I was entering my fourteenth year when, one fall, upon coming down from the arid mountains, my body morphed into that of a woman. That year, I grew to my full adult height. My father was standing by the doorstep of our house in Hermel when I went out with sporty pants on my way to the valley ten kilometers away, where my running practice took place. He stopped me: "why are you wearing pants, not shorts?" I stretched my leg, which I considered lengthy enough to be covered, and told him: "have you seen how long my leg is? I am a woman now, I cannot show my legs anymore." He frowned and ordered me to go back 
inside and wear my shorts. With my sudden growth, I no longer owned a pair that fit me. He called on my brother, who was eight years older than I was: "give her your shorts." I do not forget this piece of garment; worthy of football players, they were red, adorned with a thin white fringe, and barely reached the middle of my thighs, revealing the bottom of my ass. He told me: "go and play sports." "But people will gossip about me," I retorted, staring at the shorts. His answer still rings in my ears, like gold: "if anyone tells you anything, kick them in the mouth, then let me know and I will take care of it." I left the house with confidence, emboldened by the father who, even as he celebrated my union to a man from a different religion in the heart of Hermel, never deviated from what he had cultivated in me. "The free, unbridled stallion cannot be overpowered by the beasts."

My father contributed substantially to my education - that of the free, unbridled stallion who was stronger than the beasts, as long as she could face them - despite our many disputes throughout the years. I was stubborn, sometimes even harsh, with him. He is far away today, and I never told him that he probably was the structural condition to my liberation, if we women could really be liberated in societies that still employ all means available and imaginable to contain us.

I may not be free, since I cannot, to this day, transmit their stories with their names written, whether as victims or executioners. 